\title{
Perspective
}

PERSPECTIVE Actualité en histoire de l'art

\section{2| 2015}

United States

\section{Beyond visuality: review on materiality and affect}

\section{Veerle Thielemans}

\section{(2) OpenEdition \\ Journals}

Electronic version

URL: http://journals.openedition.org/perspective/5993

DOI: $10.4000 /$ perspective. 5993

ISSN: 2269-7721

\section{Publisher}

Institut national d'histoire de l'art

\section{Electronic reference}

Veerle Thielemans, « Beyond visuality: review on materiality and affect », Perspective [Online], 2 | 2015, Online since 07 December 2015, connection on 10 December 2020. URL : http://

journals.openedition.org/perspective/5993 ; DOI : https://doi.org/10.4000/perspective.5993

This text was automatically generated on 10 December 2020. 


\title{
Beyond visuality: review on materiality and affect
}

\author{
Veerle Thielemans
}

My special thanks go to Elisabeth Glassman, Darby English and Amy Zinck for helping me find time and space to devote to this project.

1 Art history, as practiced in the United States, is a highly self-reflective discipline that privileges the tracing of genealogies, methodical clarification, and critical positioning. Within the scholarly community there is a sense of obligation to share in debate on topics considered relevant to the present and to make one's position explicit. One of the most persistent debates over the past few decades has been the visual nature of spectatorship. Studies on the changing historical conditions of beholding, as well as the ideological constructedness of visual representations, have formed the focus of a wide spectrum of US scholarship since the 1970s. Here in France, the best known names are T. J. Clark, Jonathan Crary, Michael Fried, Rosalind Krauss, and W. J. T Mitchell, but there are many others. ${ }^{1}$ Recently, the line of inquiry on spectatorship has started to take on a different tone. With attention shifting from the predominantly visual to the physicality of artworks and their sensory/affective reception, works of art have now regained their status as "objects": objects made out of various materials, moved around, installed in particular places, taken away, exchanged for others, etc. At the same time, a new expressive vocabulary is called upon to describe the experience of looking at artworks as multisensory and affective. The emotional impact of this experience becomes part of the process of interpretation, the viewer an embodied spectator rather than a "disembodied eye."

2 This move away from visuality has been prepared from the inside, as it were, through a critique of the neutrality of the operations of looking and visual representation. Postmodern studies in art history during the 1980s and 1990s were directed against the privileging of sight since modernity, treating the paradigm of vision in Western societies as historically and socially coded. By showing how the emphasis on pure opticality concealed a control over individual subjectivity, they revealed the ideological underpinnings of this visual regime, contesting its supposed transparency. Jonathan 
Crary's groundbreaking study of the disciplinary techniques organizing vision in earlynineteenth-century European culture, for example, was one of the first to identify the insistence on modes of visual observation as a sign of unease with the discovery of the uncontrollability of physiological processes of the human body - including the mental unconscious - during this period. ${ }^{2}$ Along the same lines, race and gender studies, as well as feminist and queer scholarship, have critically examined normative cultural attitudes towards the human body, denouncing the unequal power relationships they produce. ${ }^{3}$ In addition, research on the repercussions of experiences of loss and of physical and psychic violence, which surfaced within art history in the 1990s as part of trauma studies, has been influential in making scholars attentive to the non-visual traces and pressures of painful events in the making and viewing of art. ${ }^{4}$

Within the new discipline of visual studies, furthermore, fine distinctions were introduced that have made visuality much less of a massive paradigm. For example, in 1996, the journal October published its "Visual Culture Questionnaire," in which many contributors showed reservations about the ocularcentrism of the discipline's approach; the same year, several major books argued for a more complex understanding of the workings of images. These publications underscored the effect of the physical conditions of viewing being filled with desire, moments of blindness, and resurfacing memories, as well as the importance of particular modes of displaying art objects, the weight of representational conventions, their dialogue with the art of the past, etc. I am referring here to Double Exposures: The Subject of Cultural Analysis by Mieke Bal, Good Looking: Essays on the Virtue of Images by Barbara Stafford, James Elkins' The Object Stares Back, and Michael Ann Holly's Past Looking: Historical Imagination and the Rhetoric of Images. ${ }^{5}$ The clearest case in visual studies of the increasing openness to a complex understanding of the working of images is the evolution in W.J.T. Mitchell's work. Starting with an investigation of the way in which images have been theorized as either natural or conventional and argumentation for considering the ideological mechanisms by which they are turned into naturalized signs, his subsequent work gives more and more force to the spell that images throw over us. ${ }^{6}$ What Do Pictures Want? is a brilliant demonstration of how images are simultaneously experienced as if they were alive and dead, from the most primitive idols in pre-industrial societies to today's most technologically sophisticated products. Subjects of veneration and fear, they should be considered active agents in cultural, political, and economic processes because of the almost magical dimension attached to them by humans.

4 Theoretical impulses for the reorientation of US scholarship to materiality and affect have also come from outside the discipline, foremost from social anthropology, cultural history, and philosophy, which are marked by a desire to rethink the central position occupied by language within the humanities over the past few decades and to explore other conceptual tools that undo this primacy. Meaning is said to be always under formation, unbound. Human and nonhuman relations are defined as multidirectional, fluid, non-hierarchical, depending on circumstance, and fluctuating over time. In reference to the anthropological theories of the social life of commodities (Arjun Appadurai) and distributed agency (Alfred Gell), subject/object relationships are described as interactive connections driven by needs that find their source in a network of material and social exchanges. ${ }^{7}$ Scholars have become interested in reversing the traditional understanding of the causal relationship between human activity and inanimate "things" by attributing agency to the objects themselves. Attention is called to what objects "set in motion" rather than what they "signify." ${ }^{8}$ The 
emotional impact of reflexes in the autonomic nervous system and the connections between these preverbal sensations and subsequent thought processes and actions, which are studied in psychology and the neurosciences, have made their way into the humanities through affect theory. ${ }^{9}$ Here, one of the most important sources for the reflections on the role of affect in aesthetics is Gilles Deleuze's and Felix Guattari's philosophical model of expression, which defines meaning as irrupting from intense bodily sensations which are only momentarily crystallized into signifying units. ${ }^{10}$

5 The artistic domain is unquestionably a fertile ground for investigating these propositions, since one of the properties of art objects as opposed to other objects is to act as a conduit for affective responses that subsequently opens new spaces of critical thinking. The greatest challenge is, of course, how to make these concepts workable for historical interpretation. What happens to the criterion of "objective distance" on which our discipline is founded when the sensitive experience of the work is given such an important space in historical analysis? What kind of vocabulary and rhetorical structures will have to be invented in order to verbalize embodied perception? Where does this leave artistic intention or the specifics of an artistic project -even when we have incorporated the notion that the artist is no longer the master figure in the triangle "producer, work, viewer"? The deconstruction of authorship as it has occurred in structuralist and poststructuralist thinking implied a critical study of the processes and systems that ascribed signification to things. Is there space left for such critical investigation when one takes a step away from social and political concerns, or does one stay with one's subjective response to the artwork?

6 Attention to the artwork's materiality and its effect on the viewer certainly forms a welcome re-equilibration, since social art history, which has been the prevailing tendency in North American scholarship for a very long time, has depended heavily on contextual materials, at times at the expense of the work's material makeup. Such interest does not necessarily have to signify a return to formal analysis, however, as those critical of the "material turn" seem to fear, but can be exercised in combination with an inquiry into social meaning, artistic purpose, and so on. Within the field of American studies, ambitious work has been done, for example, by scholars trained at Yale University, an important meeting place of art history and material culture studies from the 1970s until the 1990s around the figure of Jules Prown. ${ }^{11}$ Alexander Nemerov's very personal scholarship on figures such as Raphaelle and Rembrandt Peale, Timothy o'Sullivan, or Edward Hopper finds unexpected connections between individual biography, collective history, and artistic expression. ${ }^{12}$ His writings stand out as much for their close reading and literary qualities as for their novel historical configurations. Another example is Jennifer Roberts' work on late eighteenth- and early nineteenthcentury painting and illustration. Her reading of the material conditions of these objects "in transit" as a form of "agency" that is metaphorically figured within the work of John Singleton Copley, for instance, brings the history of the early American arts closer to today's concerns with economic exchange, reproduction technologies, and communication systems. ${ }^{13}$ This consequently nuances the standard accounts of nation building and artistic formation that have for so long remained closed in the history of early American art.

7 In line with anthropologically-informed studies on the cultural history of the senses, interesting work has also been undertaken on the expression/representation of sensory experience other than visual. Caroline A. Jones has been a pioneer in this area 
with her sharp critique of the ocularcentrism inherent in high modernist art criticism and her interest in artistic experiments that widen the sensory spectrum, such as body and performance art. ${ }^{14}$ Sensory reception has also become an object of study for scholars examining the effect of new media on sense experience, for instance the auditory experience of being absorbed by a radio broadcast or being engaged in a telephone conversation, which emerged as a motif in modern American painting in the first decades of the twentieth century. ${ }^{15}$ This framework also helps to engender new interpretations by setting into relief accounts that have become overfamiliar or bringing hitherto unnoticed elements to the foreground. A good example is the very active scholarship on the 1960s and 1970s, where the model of embodied perception has enabled productive re-readings of installation art, performance, and experimental film, but also of artistic forms, such as conceptual art, that seemingly downplay sensory experience.$^{16}$ Affect theory has attracted growing attention from US art historians who have extended the existing scholarship on the body and embodied experience. So far, affect studies seem to be most productive in film, dance and performance studies where the vehicle of nonverbal modes of communication passes through the body in motion. 17

8 By aligning itself with object-centered theories in anthropology, material culture, media studies, and philosophy, US art history may indeed be changing in some significant respects. Although it is too early to judge where these attempts will lead, we can briefly highlight the primary areas in which this change is the most noticeable. Whereas in the past decades the majority of US scholarship in the domains of social art history, identity studies, feminist, queer, and gender studies, institutional history, and visual studies put the investigation of the social order first in their analysis of the relationship between art and its audiences, the increasing centrality of "agency" as a working concept is reshuffling values. I still remember T. J. Clark's amused smile when asked whether works of art could have "agency" at his talk at the Institut national d'histoire de l'art in the series on social art history in December 2009. His answer was a distinct "no." Today, many US art historians would disagree with that response. Secondly, the notion that images/objects possess agency has introduced a different temporal dimension in scholarship interested in the mnemonic capacity of art. Even if research continues to be dominated by the reconstruction of historically specific contexts, art objects are recognized to have the power of reactivating sediments of earlier meanings from the past that irrupt into the present through their affective impact on the viewer. ${ }^{18}$ This notion brings US studies closer to the German and French art-historical tradition inspired by Aby Warburg's and Walter Benjamin's models of historical time that define the relation between past and present as anachronic instead of unfolding chronologically. ${ }^{19}$ This point is worth emphasizing because the use of "anachronism" as a key concept in studies that insist on the process of viewing as a sensuous encounter may seem paradoxical when the temporal experience that accompanies this process is accentuated. Michael Ann Holly, former director of the Clark Research Institute and one of the strongest spokespeople of US visual studies, is eloquent in articulating what is at stake in the affective encounter with the art of the past. While in her earlier work she had established parallels between the rhetorical structure of the art historian's text and the artwork's formal structure, in her latest book, The Melancholy of Art, it is the historical past itself that shapes the historian's text. ${ }^{20}$ The art historian has to release this potency and make it intelligible. At the same time, for Holly, this project is driven by a sense of loss. The writing of art history 
becomes a quest for origins, a search for what is no longer there. ${ }^{21}$ Finally, by making experience conditional for interpretative work, subjectivity - banned for so long from scholarship - starts to occupy a new place. This is perhaps the most surprising and potentially contestable aspect of the changes that are announcing themselves. More would need to be said on why such a return to subjectivity has become once again desirable, how it differs from the traditional role of the author, and what the consequences are for the discipline, its method and its objectives. In particular, a better understanding is needed of how this return to subjectivity is at variance with notions that preceded post-structural critique. Premises have shifted. We are more aware of our relative position in the world we live in. We recognize the opacity of language and things, the mediated nature of social relationships. Positing the scholar as a sounding board or sensor may bring US art history closer to art again, but it should not leave behind what has been learned from socially critical work. Still, the leap may be well worth taking.

\section{NOTES}

1. Among the classical texts are T. J. Clark, The Painting of Modern Life: Paris in the Art of Manet and his Followers, Princeton, 1985; Jonathan Crary, Techniques of the Observer: On Vision and Modernity in the Nineteenth Century, Boston, 1990; James Elkins, The Domain of Images, Ithaca, 1999; David Freedberg, The Power of Images: Studies in the History and Theory of Response, Chicago, 1989; Michael Fried, Art and Objecthood: Essays and Reviews, Chicago, 1998; Rosalind E. Krauss, The Optical Unconscious, Cambridge, 1994; W. J. T. Mitchell, Iconology: Image, Text, Ideology, Chicago, 1986; W. J. T. Mitchell, Picture Theory: Essays on Verbal and Visual Representation, Chicago, 1994; W. J. T. Mitchell, What do Pictures Want? The Lives and Loves of Images, Chicago, 2005; Michael Podro, Depiction, New Haven/London, 1998; Hal Foster ed., Vision and Visuality, Seattle, 1988; Norman Bryson, Michael Ann Holly, Keith Moxey eds., Visual Theory: Painting and Interpretation, New York, 1991.

2. Crary, 1990, cité n. 1

3. Among the extensive literature, some of the iconic publications are: Eve K. Sedgwick, Epistemology of the Closet, Berkeley, 1990; Douglas Crimp, Melancholia and Moralism: Essays on AIDS and Queer Politics, Cambridge, 2002; Jennifer Doyle, Sex Objects: Art and the Dialectics of Desire, Minneapolis, 2006. For a clear synthesis of new theories of embodiment, see Bernadette Wegenstein, "Body," in W. J. T. Mitchell, Mark B.N. Hansen eds., Critical Terms for Media Studies, Chicago, 2010, p. 19-34.

4. See for example: Hal Foster, The Return of the Real: The Avant-garde at the End of the Century, Cambridge, 1996.

5. "Visual Culture Questionnaire," in October, 77, Summer 1996, p. 25-70; James Elkins, The Object Stares Back: On the Nature of Seeing, New York, 1996; Mieke Bal, Double Exposures: The Practice of Cultural Analysis, Florence (KY), 1996; Michael Ann Holly, Past Looking: Historical Imagination and the Rhetoric of Images, Ithaca, 1996; Barbara Stafford, Good Looking: Essays on the Virtue of Images, Cambridge, 1996.

6. For bibliographical references, see note 1 . 
7. Arjun Appadurai, "Introduction," in The Social Life of Things, New York, 1986, p. 3-62; Alfred Gell, Art and Agency: An Anthropological Theory, Oxford, 1998. Both Appadurai and Gell argue that systems of knowledge and social relationships are determined by the circulation of goods more than their production. Another important source for this social understanding of human activity is Bruno Latour's "actor network theory."

8. "Thing theory" was first formulated by literary scholar Bill Brown of the University of Chicago but very quickly became an interdisciplinary notion shared by other disciplines in the humanities. See the special issue on "Thing theory," Critical Inquiry, 28/1, Autumn 2001; and Jane Bennett, Vibrant Matter: A Political Ecology of Things, Durham, 2010.

9. "What If? The Language of Affect," in Gillian Beer, Malcolm Bowie, Beate Perrey eds., In(ter)discipline: New Languages for Criticism, London, 2007, p. 6-24; Teresa Brennan, The Transmission of Affect, Ithaca, 2004. Melissa Gregg, Gregory J. Seigworth eds., The Affect Theory Reader, Durham, 2010.

10. See Brian Massumi, "The Autonomy of Affect," in Paul Patton ed., Deleuze, A Critical Reader, Oxford, 1996, p. 217-239. Paul Patton, Parables for the Virtual: Movement, Affect, Sensation, Durham, 2002; Erin Manning, Brian Massumi, Thought in the Act: Passages in the Ecology of Experience, Minneapolis, 2014. For an assessment of the concept of affect in the neurosciences, see Ruth Leys, "The Turn to Affect: A Critique," in Critical Inquiry, 37/3, Spring 2011, p. 434-472.

11. See Jennifer Greenhill, "Response: Look Away," in John Davis, Jennifer A. Greenhill, Jason D. LaFountain eds., A Companion to American Art, (Blackwell Companions to Art History, 6), Oxford, 2015, p. 128-145; Michael Yonan, "Toward a Fusion of Art History and Material Culture Studies," in West

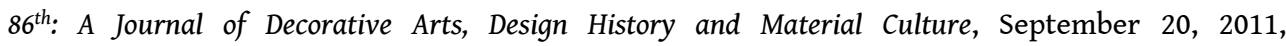
www.west86th.bgc.bard.edu (viewed on August 26, 2015).

12. Alexander Nemerov, The Body of Raphaelle Peale: Still Life and Selfhood, 1812-1824, Berkeley, 2001; also his "Ground Swell: Edward Hopper in 1939," in American Art, 22, Fall 2008, p. 50-71; and Acting in the Night: Macbeth and the Places of the Civil War, Berkeley, 2010.

13. Jennifer Roberts, Transporting Visions: The Movement of Images in Early America, Berkeley/Los Angeles, 2014.

14. See Caroline A. Jones, Eyesight Alone: Clement Greenberg's Modernism and the Bureaucratization of the Senses, Chicago, 2005; Caroline Jones ed., Sensorium: Embodied Experience, Technology and Contemporary Art, (exh. cat., Cambridge, MIT Visual Arts Center, 2006-2007), Cambridge, 2006.

15. See Leo Mazow, Thomas Hart Benton and the American Sound, University Park, 2012; Rachael DeLue, Arthur Dove: Always Connect, Chicago, 2015.

16. Film studies have taken the lead here with studies on haptic visuality, see Laura U. Marks, The Skin of the Film: Intercultural Cinema, Embodiment, and the Senses, Durham, 2000, and Jennifer M. Barker, The Tactile Eye: Touch and Cinematic Experience, Berkeley/Los Angeles, 2009. For performance studies, see among others, the anthology edited by Sally Banes and André Lepecki, The Senses in Performance, New York/London, 2007. Media historian Fred Turner analyzes the creation of extended visual and sound environments immersing the viewer in settings offering a pre-determined choice of multisensory experiences as a response to the socio-political developments in the information age that aimed at the transformation of receptive audiences into democratic citizens: The Democratic Surround: Multimedia and American Liberalism from World War II to the Psychedelic Sixties, Chicago, 2013. On conceptual art, see Eve Meltzer, Systems We Have Loved: Conceptual Art, Affect, and the Antihumanist Turn, Chicago, 2013, in which she advances the argument that conceptual art should be considered a critique of the demise of humanism that reached its apogee in the 1960 s.

17. Eve K. Sedgwick has been one of the most important authors in establishing the connection between feminist and queer scholarship and affect theories. See Eve K. Sedgwick, Touching Feeling: Affect, Pedagogy, Performativity, Durham, 2003. On performance and dance, see Carrie Noland, Agency and Embodiment: Performing Gestures/Producing Culture, Boston, 2009. 
18. For a thoughtful overview of recent theories on how art objects receive their agency from their connectedness to the past, see Keith Moxey, Visual Time: The Image in History, Durham, 2013. 19. The work by Christopher S. Wood and Alexander Nagel stands out as among the best in this area. See Alexander Nagel, Christopher S. Wood, Anachronic Renaissance, New York, 2010. Note also that social art historian Thomas Crow has singled out the "Warburg revival" as a new possibility. Thomas E. Crow, "The Practice of Art History in America," in Daedalus, 135/2, 2006, p. 87.

20. Holly, 1996, cited n. 5; also, The Melancholy Art, Princeton, 2013. A first version of this text initially appeared in The Art Bulletin with other important contributions on the conditions of historical writing by Stephen Bann, Karen Lang, and Hayden White. The Art Bulletin, 89/1, March 2007, p. 7-17.

21. This deep melancholic tone is shared by Nemerov for whom art history's final mission is the retrieval of a lost world, seizing its fragmentary apparition, and calling for it to stay through the process of writing. "Seeing Ghosts, 'The Turn of the Screw' and Art History," in Maria del Pilar Blanco, Esther Peeren eds., The Spectralities Reader: Ghosts and Haunting in Contemporary Cultural Theory, London, 2013, p. 527-547; especially: “Being a historian in the governess' sense is a matter of turning, swiveling, pointing, just like her, to direct the attention of those around you to a spot atop the tower or on the shore where something devastating and terrible stands 'as big as a blazing fire' as plain as day, only to have those others ask, and never stop asking because they never will see, 'Where?', " p. 544.

\section{INDEX}

Geographical index: États-Unis

Mots-clés: matérialité, image, affect, agentivité, objet

Keywords: materiality, image, affect, agentivity, object

\section{AUTHORS}

\section{VEERLE THIELEMANS}

Terra Foundation for American Art 